\title{
VICTIMS AND VICTIMIZERS IN JAISHREE MISRA'S ANCIENT PROMISES
}

\section{MS. SHERINE ALLENA JOSEPH ${ }^{1} \&$ DR. ANN THOMAS ${ }^{2}$}

\author{
${ }^{I}$ Ph.D. Research Scholar, Department of English, Madras Christian College, Chennai, India \\ ${ }^{2}$ Assistant Professor, Department of English, Madras Christian College, Chennai, India
}

\begin{abstract}
Gender inequality sticks to the Indian society as a plague for centuries now. Women are subjected to exploitation as a part of the differences in their gender. The concept of gender is formulated by the society and legitimized by patriarchy. As a revolt to this, women who were kept invisible have now emerged to participate in their freedom struggle. Feminist theory helps women to empower themselves from gender inequalities and discriminations that helps them to control their own life. Indian society strictly compartmentalizes the role of a woman. Adhering to the societal norms her roles are daughter, wife, and mother. A study of Indian English novels by the Indian women writers reveals the true image of Indian women. Jaishree Misra is a modern-day writer who projects herself as a spokesperson of the women who suffer under the male oppressive forces. The research paper focuses on Misra's portrayal of New- Woman in her protagonist of Ancient Promises.

Ancient Promises published in 2000 is Jaishree Misra's semi-autobiographical novel. The novel narrates the tale of her unsuccessful marriage and divorce. Misra articulates the voice of the marginalized women through her protagonist Janu. The novel elaborates Janu's journey through marriage, motherhood, and divorce. It is the tale of Janu's empowerment as a New-Woman.
\end{abstract}

KEYWORDS: Oppression, Patriarchy, Self-discovery, Empowerment, Independence

Received: Oct 11, 2020; Accepted: Oct 31, 2020; Published: Nov 11, 2020; Paper Id.: IJELOCT20201

Victims and Victimizers in Jaishree Misra's Ancient Promises

"My marriage ended today without the lightening of lamps and beating of temple drums, but in a cramped little divorce court" (Misra, 3). Jaishree Misra in her debut novel AncientPromises, records the journey of a young girl from a daughter to a daughter-in law, lover to a wife, jeans to sari, English to Malayalam and finally from a dependent woman to an independent woman.

Violence over women is a daily occurrence not just in India but across the world. Indian society, under its patriarchal influence has a different set of rules and expectations for men and women. A man is accepted because he is entitled to administer the society and family, but for a woman her role lies in maintaining the household and to serve as an obedient wife to her husband. The patriarchal society always put women under the constraints of male oppressive forces. Born as a girl child she is at first the property of her father. Marriage in the Indian society is also a transfer of this property from the father to the son-in-law. Now the girl child is her husband's possession. As noted by Prem Choudhary, "One of the dominant images of woman that has survived through history is that of the chaste woman, it continues to gain popularity especially in popular cultural forms which project this image as quintessentially that of an Indian women and as an intrinsic part of Indian culture" (Choudhary, 110 - 111). 
The early epic literatures like Ramayana reverberates the suitable behavioural patterns for women that are in complete contrast with that of men. Lord Rama speaks to his mother, "A woman attains the highest heaven merely by serving her husband... with her only interest the welfare of her husband, a woman should constantly serve him- this has been the dharma of women from ancient times, this is what the Vedas and the smritis say" (qtd.in Chaitanya, 180).

Family, in the Indian context plays an important role in deciding the social hierarchy. Family reinforces and educates their children to follow the hierarchal system. They teach their male children to be authoritative and commanding and the girl child to be tender, affectionate, devoted and unassertive. These notions of male and female appropriate behaviours are not only just a construction of the society but deeply grasped by both men and women. Being the financial support of the family man takes the superior position in the family. Women are only expected to perform the household duties of the kitchen manager and nurturing children. This difference in the status of their roles, disadvantages womenmaking them more prone to oppression and differentiation in the society.

In The Second Sex, Simone de Beauvoir eludes to the fact that gender is a concept defined by the society. The physical attributes of a woman including her ovaries and uterus are the trajectories that imprison her individuality and freedom. The physiqueof a woman makes her dependent on the patriarch, therefore her life is under the clasp of a man. Equality between the sexes is a distant dream. The legislature has amended many laws to determine the freedom of a woman, but the reality is that the laws are only written and seldom practiced. Man holds the family's economy which deprives women an opportunity to come to the fore front. By making women as the 'other' the patriarch intends to assert his power and subordinate her. By categorizing "women as the other" Beauvoir makes a parallel statement to Spivak's assortment of women as "subaltern". The word subaltern refers to those people who are marginalized by the society. Among the marginalized subaltern women are the most underprivileged because the patriarchal society limits her space everywhere. Oppression and subjugation for women seems to be a routine activity that is demanded by their status roles. The tales of resistance and revolt against this oppression are often unheard voices.

Jaishree Misra's Ancient Promises has its plot set in the contemporary Kerala culture. Just as the title "Ancient Promises", the novel talks about some ancient promises that are still expected to be followed. The novel is a reflection of the female psyche of the Indian women from the contemporary society that narrates the story of the struggles of women to disentangle the handcuffs of oppression meted on to them by the patriarchal society.

Janu, a Delhi brought up girl is the protagonist of the Novel. She has her familial roots laid down deep in the traditional customs of the Kerala culture. She was hastened to a marriage with Suresh after her parents discover her loverelationship with Arjun, a Delhi boy. Janu's parents had strong contempt against love marriages.

I was fairly sure my parents would disapprove; I'd heard Dad harrumph loudly at love scenes in films, worried they would fill my head with silly notions. Love, for him, had been the stirring in his heart when his mother had shown him the picture of a fresh- faced girl she'd chosen for him to marry, eighteen years ago. This running - around - trees business was for film stars and fools, he often said (Ancient Promises23-24)

Marriage according to the culture of Kerala culture is a divine institution. Society considers the primary role of a girl child is to get herself prepared for matrimony. Being deep rooted in the culture, Janu's parents strictly adhere to the codes and conducts of the society. As traditional people they were unable to accept the fact that their daughter against the wishes of her parents decides her own life. Being obedient to the patriarchal system Janu's parents left the major decision 
of their life for the patriarchs to decide. Therefore, they wanted their daughter also to do the same. For them Janu's world was an incompatible one.

My world was a confusing one for them. They were so sure that I would be safest among my own people, marrying eventually into my own community. But I had all kinds of friends and all kinds of experiences that were alien and that couldn't be stopped. Arjun, unfortunately, would fall firmly into that category - he was the wrong age (too young), wrong community (not Malayali), and came at the wrong time (I was too young) (Ancient Promises, 26).

Thus, starts the effects of patriarchal oppression on Janu. Janu was denied higher education and was forced into a marriage with Suresh an eligible bachelor from a wealthy business family, the Maraar's on her eighteenth birthday. Her feeble protests of "I don't feel ready for a marriage... I'm looking forward to going to college here" (54) did not work. She was made to believe that adolescent love however strong and deep will not be able to survive the onslaught of family and society. Janu thus sacrifices her love for Arjun. For her marriage was to "ensure that I began to pay off some of the debts that had accrued against my name somewhere." (68).

The wedding ceremony teaches Janu some of the rules and regulations to be followed by her as a wife. Janu is expected to accompany and be his shadow always satisfying his needs, nothing more. The Maraar house was a hub of dos and don'ts to be followed by a wife, especially for a girl like Janu who was brought up outside Kerala.

She "had not been the Choice Number One on Amma's short list of daughters - in- law" (96). She learns from her in - laws that she was selected to be Suresh's bride just because she fitted into all the specifications he laid down.

For her dominating mother-in-law, bullying sisters-in-law and the restrained father-in-law, she is the modern city born not schooled in Kerala ways. Thus, Janu was not accepted wholly by anyone in the Maraar family. Suresh was also an indifferent husband. He was very much occupied with his business matters and did not notice his young wife's struggle to lay her roots in his household.Janu as a young girl battled against her in-law's surreptitious ridicules that deprived her individuality. Suresh was always a silent spectator whenever he witnessed the insults meted on his young wife. He was inconsiderate to know her sufferings.

When Maraar's older daughter - in - law Latha, gave birth to a baby boy it was a great celebration in the house. Janu thought she might be more approved in the household if she too gives birth to a child - that too a baby boy. To her much disappointment the girl child who is mentally handicapped, born to her did not fetch her the key of the Maraar's heart.

The novel witnesses Janu's struggle to save her marriage and nurture a child with mental disability. She derives her own conclusion by accepting Riya's disability and reconciling with her Karma. "Somewhere in my distant past, perhaps even a thousand years ago, I'd done something that committed me to dedicating this life to Riya's care" (160).

She finally understands that education is the only way by which she can escape. "If I did leave Kerala with a baby and no education to speak of, how far could I go?" She asks herself. She acquires a BA and an MA through distance education. Janu decides to free herself from carrying the burden of subverting her individuality to please her in-laws and to live according to their expectation. Janu stands against her mother - in - law when she was asked to leave Riya under the care of the servants to attend a wedding. At last she grabs the courage to stand against the age-old question of "what will people say? And what will the Maraar's say?" (160). 
She meets Arjun, her adolescent love in her trip to Delhi to secure a scholarship that will financially support her foreign education. After her marriage in all these years he was only a vague memory in her, but she freely embraces adultery with Arjun as though she is doing something natural. She breaks the cardinal rule of marriage without any hesitation and regret.

Janu intends to break her marriage with Suresh because they were "like prisoners who hated each other but were forced to serve endless sentences side by side" (243). When she narrates the episodes,she went through while in Delhi to Suresh she feels her burden moving from her to Suresh's shoulders, "I was no longer the injured party, he was!" (219). In return Janu expects jealousy and anger from the Maraar's, instead their plot was different to picture Janu as insane and thereby taking possession of Riya and destroying her mentally. She was drugged to depression but finally she arises from all those and manages to reach London.

Embodied and empowered by the support of Arjun and his love, Janu resists the oppressions that forced her to surrender her individuality with the hope that her sufferings till date will pay the debts of her Karma. Empowered Janu, breaks the clutches of the society that detained her as a marginalized 'other' and transforms herself as a 'New-Woman'. Janu's return from London manifests her change as an assertive individual.

For Janu, it was education that catalysed her empowerment and her experience in London transforms her from a victim of patriarchal oppression to a new empowered woman who cannot be defeated so very easily. She fights against the society's resistance to change. The transition from being a victim to an agent of change for Janu is a slow and gradual process. Janu who once silently suffered all the oppressions believing it to be her karma was willing to pay the price for it.The diverse episodes of oppression and freedom install in Janu the courage to bespeak the trajectories of the Indian women. Janu manifests a successful tale of evolution as a 'New-Woman'.

Misra leaves the story open ended with Janu not flying back to Englandand to Arjun but on her own, venturing into the Kerala night, with her unlikely band of supporters, Ma, Ammuma and Riya. Armed with the knowledge that she has at last, paid all her debts both ancient and new ones, she frees herself from all the shackles.

Jaishree Misra joins the realm of women writers who ultimately breaks the traditional stereotypes of suffering and passive women and plots the evolution of the New-Woman. Misra roots her protagonist Janu into a culture where the concept of 'self', individualism and protests were unearthly ideas for a woman. Janu is placed in a society that considers marriage as the be-all and end-all of a woman's life. Misra's Janu journeys from a meek and submissive woman, subordinated by her father and husband to a bold New-Woman, breaking the clutches of patriarchal oppressive forces and free herself to an independent life.

Janu is Misra's spokesperson who transforms herself to a New-Woman. Through Janu, Misra draws the attention of her readers to guard them against patriarchal oppression and explore their inner 'self' through self-discovery. Janu emerges as a New-woman capable of doing all that men could do, even better than men.

Misra's portrait of Janu asserts Simone de Beauvoir states that, "Thus humanity is male and man defines women not in herself but as relative to him; she is not regarded as an autonomous being" (Beauvoir, 46). Misra delves deep into the inner psyche of Janu. She frees Janu's entrapped psyche and evolves her as a 'New-Woman'.

During the late nineteenth century 'New-Woman' concept gained more importance. Coined by Sarah Grand the term denotes an independent woman. The New-Woman advocates economic independence and rejects the traditional 
stereotypical codes of a woman. New-Woman is assertive in nature, autonomous in her deeds and embraces her true 'self'. The New-Woman is an urban middle-class woman, but not a silent sufferer as she used to be. She modifies her values, seeks new identity, and recognizes her 'self'.

Janu traverse through tradition, transition, and transformation. She is the personification of New-Woman, breaking the years of burden that made her bent her shoulders. Janu represents those women who want their individuality to be recognized. She traverses through the 'road not taken' to emerge as an independent and assertive New-Woman. She discovers her female potential and identifies her 'self'. She emerges as a revolutionary asserting her 'self' and achieving economic independence.

\section{REFERENCES}

\section{PRIMARY SOURCE}

1. Misra, Jaishree. Ancient Promises: A heartrending story of love and family loyalty. New Delhi: Penguin Books India, 2000. Print

\section{SECONDARY SOURCES}

1. Chowdhry, Prem. "Imagined Lovers: Ideology, Practice and Social Hierarchies."Women of India: Colonial and Postcolonial Periods. Ed. Bharathi Ray. New Delhi: Sage Publishers, 2005. Print.

2. Chaithanya, Satya. "Female Subversion: The Spirit of Lilith in Indian Culture." IndianLiterature L.3, 2006. Print.

3. De Beauvoir, Simone. The Second Sex. Trans. H.M Parshley. New Delhi: Random House, Vintage Books.1952. Print.

4. HERMIT, JYOTI TABITA. "ENVIRONMENTAL STEWARDSHIP: EMERGING TRENDS IN CHRISTIAN ECOLOGICAL ETHICS." International Journal of English and Literature (IJEL) 5.1, Feb 2015, 97-104

5. RANI, G. SWARUPA, and NASREEN BANU. "RELATIONSHIP BETWEEN LIFE-SATISFACTION AND WISDOM OF RETIRED PROFESSIONALS." International Journal of Educational Science and Research (IJESR) 8.1, Feb 2018, 19-24

6. SELVARAJ, A. "AN ACCEPTANCE OF EXISTENT SELF: A CRITICAL STUDY OF SAUL BELLOW'S THE VICTIM." International Journal of English and Literature (IJEL) 5. 6, Dec 2015, 41-46

7. Spivak, Gayathri Chakaravarthy.Can the SubalternSpeak? ${ }^{S T}$ August 2014 http://www.mcgrill.ca/files/crclaw-discourse/caanthe-subaltern-speak.pdf. web

8. VARGHESE, SUSAN G., and DEEPA MARY FRANCIS. "FICTIONAL REFLECTIONS OF SOCIAL REALITY: A CROSSCULTURAL READING." International Journal of English and Literature (IJEL) 3.4, Oct 2013, 149-154 
